\title{
Evaluasi Penggunaan E-filling pada Wajib Pajak di KPP Pratama Pasar Minggu 2015-2018
}

\author{
Wening Estiningsih ${ }^{1}$, Hardian Mursito ${ }^{2}$, Heri Nurranto ${ }^{3}$ \\ 1 Universitas Indraprasta PGRI \\ 2 Universitas Indraprasta PGRI \\ 3 Universitas Indraprasta PGRI
}

\begin{tabular}{|c|c|}
\hline ARTICLE INFO & ABSTRACT \\
\hline $\begin{array}{l}\text { Article History: } \\
\text { Received Mei } 12^{\text {th }}, 2021 \\
\text { Revised July } 24^{\text {th }}, 2021 \\
\text { Accepted Aug } 13^{\text {th }}, 2021\end{array}$ & $\begin{array}{l}\text { The change in service includes services to wp, from initially having to submit the } \\
\text { taxpayer to the Tax Service Office (KPP) directly, making submitting SPT online } \\
\text { anywhere and anytime. In addition, the use of e-filling can reduce the burden on } \\
\text { the administration process of tax reports using paper, e-filling plays a very } \\
\text { important role in minimizing the inaccuracy of SPT reporting data. The purpose of }\end{array}$ \\
\hline $\begin{array}{l}\text { Keywords: } \\
\text { Taxs; } \\
\text { E-filling; } \\
\text { E-spt reporting. }\end{array}$ & $\begin{array}{l}\text { this study is to evaluate the use of e-filling on individual taxpayers at KPP Pratama } \\
\text { Pasar Minggu. The research method used is a qualitative method. The results of } \\
\text { this study show that the number of registered taxpayers from year to year } \\
\text { continues to increase and the most number are employees of corporate taxpayers } \\
\text { and non-employee taxpayers, meanwhile, SPT reporting uses e-filling from } 2015 \\
\text { to year. } 2019 \text { has increased by around } 58 \% 2019 \text { from the number of taxpayers } \\
\text { registered at the KPP, while it is inversely proportional to manual submission of } \\
\text { tax returns, which means that taxpayers have begun to adapt to tax } \\
\text { modernization. }\end{array}$ \\
\hline
\end{tabular}

Perubahan layanan meliputi pelayanan kepada WP, dari awalnya harus menyerahkan wajib pajak ke Kantor Pelayanan Pajak (KPP) secara langsung, membuat pengajuan SPT secara online di mana saja dan kapan saja. Selain itu, penggunaan e-filling dapat mengurangi beban proses administrasi laporan pajak menggunakan kertas, e-filling memainkan peran yang sangat penting dalam meminimalisir ketidakakuratan data pelaporan SPT. Tujuan dari penelitian ini adalah untuk mengevaluasi penggunaan e-filling pada wajib pajak orang pribadi di KPP Pratama Pasar Minggu. Metode penelitian yang digunakan adalah metode kualitatif. Hasil penelitian ini menunjukkan bahwa jumlah wajib pajak terdaftar dari tahun ke tahun terus meningkat dan jumlah terbanyak adalah karyawan wajib pajak badan dan wajib pajak non-karyawan, sementara itu, pelaporan SPT menggunakan e-filling dari tahun 2015 hingga tahun. Tahun 2019 mengalami peningkatan sekitar $58 \%$ tahun 2019 dari jumlah wajib pajak yang terdaftar di KPP, sementara itu berbanding terbalik dengan penyampaian SPT secara manual, yang berarti wajib pajak dapat melakukan pendataan.

Corresponding Author:

Wening Estiningsih,

Email: wening.nextgen007@gmail.com

How to Cite: Estiningsih, W., Mursito, H., Nurranto, H. (2021). Evaluasi penggunaan e-filling pada wajib pajak di KPP Pratama Pasar Minggu 2015-2018 . Sosio e-Kons, 13 (2), 109-115. http://dx.doi.org/10.30998/sosioekons.v13i2.9762

\section{PENDAHULUAN}

Pajak adalah kontribusi wajib kepada negara berdasarkan undang-undang, dengan tidak mendapatkan imbalan secara langsung dan digunakan untuk keperluan negara bagi sebesar-besarnya kemakmuran rakyat (Pemerintah Republik Indonesia, 2004). Era globalisasi yang identik dengan pertumbuhan teknologi saat ini, telah mengubah banyak hal hampir di seluruh aspek kehidupan 
manusia. Teknologi Informasi berkenaan dengan internet (cyberspace) telah digunakan dalam banyak sektor kehidupan, mulai dari perdagangan/bisnis (e-Commerce), pendidikan (e-Education), kesehatan (Telemedicine) bahkan sampai di bidang pemerintahan (e-Government) (E.S. Wiradipradja dan D. Budhijanto, 2002).

Mengantisipasi perkembangan teknologi tersebut, Direktorat Jenderal Pajak (DJP) berusaha memenuhi aspirasi wajib pajak (WP) dengan mempermudah tata cara pelaporan, Surat Pemberitahuan (SPT) masa maupun tahunan. Pengembangan sistem perpajakan yang dilakukan Direktorat Jenderal Pajak (DJP) tersebut tidak lain adalah sebagai bagian dari reformasi perpajakan khususnya administrasi perpajakan. Direktorat Jenderal Pajak, setiap tahun memiliki target capaian pajak dan merealisasikannya. Berikut ini adalah data tabel target dan realisasi dari Indikator Kinerja Utama (IKU) Kementerian Keuangan Republik Indonesia tahun 2017.

Tabel 1.

Target dan Realiasasi IKU Kemenkeu, Direktorat Jenderal Pajak (DJP) tahun 2017

\begin{tabular}{|c|c|c|c|c|}
\hline $\begin{array}{l}\text { Kode } \\
\text { SS/IKU }\end{array}$ & Sasaran Strategis/lKU & Target & $\begin{array}{l}\text { Realiasasi } \\
(\%)\end{array}$ & $\begin{array}{c}\text { Indeks } \\
\text { Pencapaian }\end{array}$ \\
\hline $1 \mathrm{a}-\mathrm{CP}$ & Presentase realiasasi penerimaan pajak & $100 \%$ & 89,68 & 89,68 \\
\hline $2 \mathrm{a}-\mathrm{CP}$ & $\begin{array}{l}\text { Persentase tingkat kepatuhan formal WP Badan dan OP Non } \\
\text { Karyawan }\end{array}$ & $50,00 \%$ & 62,96 & 120,00 \\
\hline $2 b-\mathrm{N}$ & $\begin{array}{l}\text { Persentase pertumbuhan jumlah WP Badan dan OP Non } \\
\text { Karyawan yang melakukan pembayaran }\end{array}$ & $25,00 \%$ & 32,73 & 120,00 \\
\hline $3 a-N$ & Persentase penyampaian SPT melalui e-Filing & $78,00 \%$ & 85,72 & 109,90 \\
\hline $5 a-N$ & Persentase efektivitas kegiatan penyuluhan & $55 \%$ & 97,52 & 120,00 \\
\hline $6 \mathrm{a}-\mathrm{N}$ & $\begin{array}{l}\text { Persentase WP Badan dan OP Non Karyawan yang terdaftar } \\
\text { tahun berjalan dan WP TLTB yang melakukan pembayaran }\end{array}$ & $100,00 \%$ & 93,87 & 93,87 \\
\hline $7 a-N$ & Persentase himbauan SPT yang selesai Ditindaklanjuti & $100,00 \%$ & 120,00 & 120,00 \\
\hline
\end{tabular}

Sumber: Direktorat Jenderal Perpajakan, 2017

Perubahan mendasar yang berkaitan dengan modernisasi pajak terjadi pada 2004, dimana Direktorat Jenderal Pajak (DJP) berusaha untuk memenuhi aspirasi wajib pajak (WP) dengan mempermudah tata cara pelaporan. Hal itu ditandai dengan dikeluarkannya Keputusan Direktur Jendral Pajak Nomor KEP-88/PJ/2004, tanggal 14 mei 2004 tentang penyampaian SPT secara elektronik. Presiden Republik Indonesia bersama-sama dengan Direktorat Jenderal Pajak (DJP) meluncurkan produk e-filling atau Elektronic Filling System sebagai sistem pelaporan pajak SPT secara eletronik (efilling) yang dilakukan melalui sistem online yang real time.

Perubahan pelayanan tersebut meliputi pelayanan kepada wajib pajak (WP) dari yang semula WP harus menyampaikan ke Kantor Pelayanan Pajak (KPP) secara langsung menjadi penyampaian pelaporan pajak secara online yang dapat dilakukan dimana saja dan kapan saja. Penggunaan e-filling diharapkan mampu mengurangi biaya maupun beban proses administrasi dalam proses pelaporan pajak. E-filling sangat berperan dalam meminimalisir kesalahan data pelaporan SPT. Hal ini sejalan dengan pendapat (Mujiyati et al., 2015), bahwa secara keseluruhan dengan menggunakan e-filing, pelaporan SPT akan lebih akurat dan dengan proses yang lebih cepat, sehingga lebih efektif dan efisien. Sistem e-filling dapat dikatakan sukses dalam pelaksanaanya sebagai penerimaan SPT tahunan karena dari segi kontrol perilaku, tingkat kegunaan, tingkat kemudahan dan perilaku sosial sudah mendukung kinerja dari sistem e-filling itu sendiri (Gani et al., 2020).

Tabel 2.

Destination Statement Direktorat Jenderal Pajak Tahun 2015-2019

\begin{tabular}{lccccc}
\hline \multicolumn{1}{c}{ Indikator } & $\mathbf{2 0 1 5}$ & $\mathbf{2 0 1 6}$ & $\mathbf{2 0 1 7}$ & $\mathbf{2 0 1 8}$ & $\mathbf{2 0 1 9}$ \\
\hline Tax Ratio & $13,2 \%$ & $14,2 \%$ & $14,6 \%$ & $15,2 \%$ & $16 \%$ \\
Penerimaan Pajak & 1.294 T & 1.512 T & 1.737 T & $2.007 \mathrm{~T}$ & $2.329 \mathrm{~T}$ \\
SPT e-Filing & 2 Juta & 7 Juta & 14 Juta & 18 Juta & 24 Juta \\
Jumlah WP terdaftar & 32 Juta & 36 Juta & 40 Juta & 42 Juta & 44 Juta \\
\hline
\end{tabular}

Sumber: Direktorat Jenderal Perpajakan, 2017 
Berdasarkan tabel di atas dapat diketahui bahwa penerimaan pajak dan jumlah wajib pajak (WP) terdaftar dari tahun 2015 sampai tahun 2019 selalu mengalami peningkatan. Hal yang sama juga terjadi pada pelaporan SPT pada rentang tahun tersebut juga mengalami peningkatan. Peningkatanpeningkatan ini menjadi hal positif bahwa wajib pajak (WP) sudah memiliki kesadaran dan kemapuan untuk beralih dari penyampain secara tradisional ke penyampaian SPT secara modern.

Direktur Teknologi Informasi Direktorat Jenderal Pajak (DJP) Iwan Djuniardi mengatakan, fasilitas e-filling sudah diperkenalkan kepada WP sejak 2004. Saat itu Direktorat Jenderal Pajak (DJP) masih menggunakan penyedia jasa aplikasi atau Application Service Provider, tepat tahun lalu 2012. DJP juga memberikan kesempatan kepada wajib pajak (WP) pribadi untuk mengisi e-filling melalui website Direktorat Jenderal Pajak (DJP). Kendati fasilitas tersebut bertujuan untuk mempermudah wajib pajak (WP) melaporkan kewajibannya kepada Direktorat Jenderal Pajak (DJP), perkembangan penggunaan e-filling hanya sebanyak 18 Juta SPT. Sementara jumlah wajib pajak (WP) pribadi mencapai 42 juta jiwa. Wajib pajak yang sudah menggunakan e-filling masih minim, dari total penduduk Indonesia sebanyak 260 juta jiwa.

Saat ini belum semua Wajib Pajak menggunakan e-filling karena kurangnya sosialisasi dari Direktorat Jenderal Pajak (DJP) atau mungkin Wajib Pajak belum bisa menerima sebuah teknologi baru dalam pelaporan pajaknya. Pola pikir dari Wajib Pajak yang masih menganggap penggunan sistem komputer dalam pelaporan SPT akan lebih menyulitkan jika dibandingkan secara manual juga berperan besar, padahal pelaporan SPT secara komputerisasi memiliki manfaat yang lebih besar bagi Wajib Pajak maupun Direktorat Jenderal Pajak (DJP). Hasil penelitian (Gani et al., 2020), setidaknya terdapat 2 (dua) hal penting yang tentang penggunaan e-filling yaitu bahwa sistem e-filling memiliki taraf signifikansi yang baik mulai dari segi kontrol perilaku, tingkat kegunaan, tingkat kemudahan dan perilaku sosial, akan tetapi sistem e-filling sedikit memiliki kelemahan yaitu pada segi kemudahan penggunaan dan perilaku pengguna namun nilainya dapat dikatakan cukup baik hanya saja pada sikap penggunaan sistem yang memiliki nilai kurang. Sementara penelitian kuantitatif (Mujiyati et al., 2015) menganlisis faktor untuk mengetahui pengaruh variabel independen persepsi kemudahan, persepsi kegunaan, kompleksitas, kesukarelaan, pengalaman, keamanan dan kerahasiaan, serta kesiapan teknologi informasi wajib pajak terhadap variabel dependen yaitu intensitas penggunaan e-filing baik di KPP Surakarta maupun di KPP Sukoharjo. Mendasarkan pada uraian-uraian tersebut di atas, maka penelitian ini merupakan penelitian kualitatif untuk menganalisis permasalahan pada evaluasi penggunaan e-filling pada wajib pajak di KPP Pratama Pasar Minggu 2015-2018.

\section{METODE}

Metode yang digunakan dalam penelitian ini menggunakan metode kualitatif. Teknik pengumpulan data dikumpulkan berasal dari data sekunder. Teknik pengolahan data dengan menggunakan metode penelitian analisis deskriptif dengan menguraikan secara menyeluruh terhadap pelaksanaan prosedur penggunaan e-filling. Penelitian ini merupakan kualitatif bersifat evaluasi yaitu kegiatan untuk mengumpulkan informasi tentang bekerjanya sesuatu, yang selanjutnya informasi tersebut digunakan untuk menentukan alternatif yang tepat dalam mengambil keputusan (Sukmadinata, 2009).

\section{HASIL DAN PEMBAHASAN}

Indonesia merupakan negara sedang berkembang urutan nomor 4 di dunia terpadat penduduknya setelah Cina, India, Amerika Serikat (USA) dengan kepadatan penduduk sebanyak: 260.580.739 jiwa, dengan rasio: 3,5\% dari jumlah penduduk dunia, dengan pendapatan devisit atau APBN berasal dari pajak. Perhatian pemerintah terhadap pajak yang merupakan bagian dari 
pendapatan negara maka pemerintah melalui Dinas Perpajakan melakukan perubahan modernisasi pajak. Adapun perubahan yang utama adalah modernisasi pajak, dimana Direktorat Jenderal Pajak (DJP) berusaha untuk memenuhi aspirasi wajib pajak (WP) dengan mempermudah tata cara pelaporan SPT. Selanjutnya, pada tanggal 14 Mei 2004, hal itu dikeluarkan Keputusan Direktur Jendral Pajak Nomor KEP-88/PJ/2004 tentang penyampaian SPT secara elektronik. Presiden Republik Indonesia bersama Direktorat Jenderal Pajak (DJP) memperkenalkan produk e-filling atau Electronic Filling System yaitu sistem pelaporan pajak SPT eletronik (e-filling) yang dilakukan dengan sistem online serta real time. Seiring dengan kemajuan teknologi, Pemerintah telah menyediakan e-SPT Masa PPh untuk membuat laporan pajak di aplikasi online pajak dan bisa diakses secara gratis oleh wajib pajak melalui https://djponline.pajak.go.id.

Perubahan pelayanan tersebut meliputi pelayanan kepada wajib pajak dari yang semula wajib pajak (WP) harus menyampaikan ke Kantor Pelayanan Pajak (KPP) secara langsung, tapi sekarang menyampaikan SPT dapat dilakukan secara online dimana saja dan kapan saja. Selain itu penggunaan e-filling dapat mengurangi beban proses administrasi laporan pajak menggunakan kertas, e-filling sangat berperan dalam meminimalisi ketidakakuratan data pelaporan SPT.

Surat Pemberitahuan (SPT) adalah laporan pajak yang disampaikan kepada pemerintah Indonesia melalui Direktorat Jenderal Pajak.Ketentuan mengenai SPT diatur dalam Undang-Undang Nomor 28 Tahun 2007 tentang Ketentuan Umum dan Tata Cara Perpajakan. Dalam undang-undang ditegaskan dan dinyatakan oleh pemerintah mengharuskan seluruh wajib pajak untuk melaporkan SPT sesuai dengan ketentuan yang berlaku (Undang-Undang No. 28 Tahun 2007). Dalam ketentuan tersebut, secara garis besar dapat disimpulkan bahwa fungsi dari SPT adalah:

1. melaporkan pelunasan atau pembayaran pajak yang sudah dilakukan, baik secara personal maupun melalui pemotongan penghasilan dari perusahaan dalam jangka waktu satu tahun.

2. melaporkan harta benda yang dimiliki di luar penghasilan tetap dari pekerjaan utama.

3. melaporkan penghasilan lainnya yang termasuk ke dalam kategori objek pajak maupun bukan objek pajak.

\section{Penggunaan e-Filling bagi WPOP}

Setiap pekerja/pegawai pasti menerima bukti potong sebagai bukti setoran pajak yang telah dipungut dan dilaporkan oleh perusahaan pemberi kerja. Formulir bukti potong tersebut terbagi menjadi dua yakni 1) Formulir $1721 \mathrm{~A} 1$ khusus untuk para karyawan yang bekerja di perusahaan milik swasta dan 2) Formulir 1721 A2 untuk karyawan yang menjabat sebagai Pegawai Negeri Sipil.

Kedua formulir ini nantinya akan menjadi pedoman wajib pajak ketika lapor pajak. Selain formulir bukti potong, kita juga mengenal tiga jenis formulir SPT PPh Orang Pribadi, yakni formulir 1770 yang ditujukan bagi wajib pajak yang bekerja tanpa ikatan kerja tertentu, formulir 1770 SS yang ditujukan untuk perseorangan atau pribadi dengan jumlah penghasilan kurang dari atau sama dengan Rp 60 juta setahun dan hanya bekerja pada satu perusahaan, serta formulir $1770 \mathrm{~S}$ untuk wajib pajak pribadi dengan penghasilan tahunan lebih dari Rp 60 juta dan bekerja pada dua perusahaan atau lebih.

Untuk yang manual bisa dilakukan di seluruh Kantor Pelayanan Pajak (KPP) di Indonesia dengan melakukan pengisian data penghasilan. Dalam formulir SPT terdapat beberapa kolom yang harus diisi seperti nilai harta. Contohnya seperti rumah, kendaraan, perhiasan, dan deposito yang nilainya material. Formulir sudah diisi sesuai yang ditentukan, maka tahap selanjutnya mengambil nomor antrean pembayaran di KPP, setelah itu menyerahkan berkas kepada petugas di loket untuk diproses, dan selanjutnya mendapatkan bukti penyerahan SPT. Untuk proses secara manual kebanyakan masih dikeluhkan oleh masyarakat lantaran antreannya yang panjang. Dengan begitu, Direktorat Jenderal Pajak (DJP) menyediakan pelaporan secara online melalui e-filing. Menurut Hestu Yoga Saksama (2017), "Pakai e-filing sangat nyaman, tidak perlu harus antre ke kantor pajak".

Untuk dapat melakukan e-filling, melalui tiga tahapan utama. Dua tahapan yang pertama hanya dilakukan sekali saja. Sedangkan tahapan ketiga dilakukan setiap menyampaikan SPT. Ketiga tahapan tersebut meliputi: 
1. Mengajukan permohonan E-FIN ke Kantor Pelayanan Pajak terdekat yang merupakan nomor identitas wajib pajak (WP) bagi pengguna e-filing. Karena hanya sekali digunakan, Anda hanya perlu sekali saja mengajukan permohonan mendapatkan E-FIN tersebut.

2. Mendaftarkan diri sebagai WP e-filing di situs DJP paling lama 30 hari kalender sejak diterbitkannya $E-F I N$.

3. Menyampaikan SPT Tahunan PPh WP Orang Pribadi secara e-filing melalui situs Direktorat Jenderal Pajak (DJP) melalui empat langkah prosedural saja, yaitu:

a. Mengisi e-SPT pada aplikasi e-filing di situs Direktorat Jenderal Pajak (DJP);

b. meminta kode verifikasi untuk pengiriman e-SPT, yang akan dikirimkan melalui email atau SMS;

c. mengirim SPT secara online dengan mengisikan kode verifikasi;

d. notifikasi status e-SPT dan Bukti Penerimaan Elektronik.

\section{Data Penggunaan e-Filling}

Pengguna e-filling oleh wajib pajak di Indonesia, sejak diperkenalkan dengan modernisasi pajak terus mengalami perkembangan positif, baik wajib pajak pribadi maupun badan. Adapun perkembangan jumlah wajib pajak dan penggunaan e-filling oleh wajib pajak di jelaskan pada tabel berikut.

Tabel 3.

Data Jumlah Wajib Pajak KPP Pasar Minggu 2015-2019

\begin{tabular}{|c|c|c|c|c|c|c|c|}
\hline \multirow[b]{2}{*}{ No } & \multirow[b]{2}{*}{ Tahun } & \multirow[b]{2}{*}{ Nama KPP } & \multirow[b]{2}{*}{ Badan } & \multicolumn{3}{|c|}{ Orang Pribadi } & \multirow{2}{*}{$\begin{array}{l}\text { Total } \\
\text { WP }\end{array}$} \\
\hline & & & & Karyawan & $\begin{array}{c}\text { Non } \\
\text { karyawan }\end{array}$ & Total & \\
\hline 1 & 2015 & KPP Pratama Pasar minggu & 5 juta & 20 juta & 7 juta & 27 juta & 32 juta \\
\hline 2 & 2016 & KPP Pratama Pasar Minggu & 7 juta & 21 juta & 8 juta & 29 juta & 36 juta \\
\hline 3 & 2017 & KPP Pratama Pasar Minggu & 8 juta & 23 juta & 9 juta & 32 juta & 40 juta \\
\hline 4 & 2018 & KPP Pratama Pasar Minggu & 9 juta & 24 juta & 9 juta & 33 juta & 42 juta \\
\hline 5 & 2019 & KPP Pratama Pasar Minggu & 9 juta & 25 juta & 10 juta & 45 juta & 44 juta \\
\hline
\end{tabular}

Sumber : KPP Pratama yang telah di olah

Berdasarkan tabel di atas dapat diketahui bahwa wajib pajak di KPP Pasar minggu selalu mengalami peningkatan di setiap tahunnya. Pada 2016 total wajib pajak meningkat $12,50 \%$ dari 2015 , tahun 2017 meningkat 11,11\% dari 2016, sedangkan 2018 dan 2019 masing-masing mengalami peningkatan dari periode sebelumnya yaitu 5,00\% dan 4,76\%. Jika dilihat dari wajib pajak Badan maka kenaikan wajib pajak sebanyak 1 juta wajib pajak disetiap tahun, kecuali pada 2019 wajib pajak Badan tidak mengalami peningkatan. Hal yang hampir sama terjadi pada peningkatan wajib pajak karywan yang rata rata meningkat 1 juta setaip tahunnya. Peningkatan wajib pajak karyawan terbesar terjadi pada tahun 2017 yang meningkat 2 juta wajib pajak dari periode 2016. Demikian pula yang terjadi pada wajib pajak non karyawan mengalami peningkatan 1 juta setiap tahun, kecuali 2018 yang konstan sebanyak 9 juta wajib pajak seperti peridoe 2017.

Perkembangan pengguna e-filling oleh wajib pajak sejak di perkenalkan tahun 2014 diilustrasikan secara singkat pada tabel berikut ini.

Tabel 4.

Persentase Penggunaan e-Filling

\begin{tabular}{llllll}
\hline \multicolumn{1}{c}{ Uraian } & \multicolumn{1}{c}{$\mathbf{2 0 1 5}$} & \multicolumn{1}{c}{$\mathbf{2 0 1 6}$} & \multicolumn{1}{c}{$\mathbf{2 0 1 7}$} & \multicolumn{1}{c}{$\mathbf{2 0 1 8}$} & $\mathbf{2 0 1 9}$ \\
\hline Jumlah wajib pajak terdaftar & 32 juta & 36 juta & 40 juta & 42 juta & 44 juta \\
Penyampaian SPT menggunakan E-filling & 2 juta & 7 juta & 14 juta & 18 juta & 24 juta \\
Persentase & $6 \%$ & $16 \%$ & $44 \%$ & $56 \%$ & $58 \%$ \\
Jumlah wajib pajak terdaftar & 32 juta & 36 juta & 40 juta & 42 juta & 44 juta \\
Penyampaian SPT non e-filling & 30 juta & 29 juta & 26 juta & 24 juta & 20 juta \\
Persentase & $94 \%$ & $84 \%$ & $56 \%$ & $52 \%$ & $51 \%$ \\
\hline
\end{tabular}

Sumber: KPP Pratama yang telah diolah 
Dari data di atas diketahui bahwa wajib pajak yang terdaftar dari tahun ke tahun terus meningkat dan yang paling banyak jumlahnya adalah karyawan dari pada wajib pajak badan serta wajib pajak non karyawan, sementara itu pelaporan SPT menggunakan e-filling dari tahun 2015 hingga tahun 2019 mengalami kenaikan sekitar hingga mencapai angka 58\% di tahun 2019 dari jumlah wajib pajak yang terdaftar pada KPP tersebut, sementara berbanding terbalik dengan penyampaian SPT secara manual mengalami penurunan yang berarti para wajib pajak sudah mulai beradaptasi dengan modernisasi pajak.

Dari data-data tersebut, sistem pelaporan pajak e-filling telah memberikan keberhasilan yang cukup baik. Namun begitu penyampaian pajak secara tradisional masih tetap tinggi, sehingga peluang untuk meningkatkan pelaporan pajak melalui e-filling masih sangat terbuka. Wajib pajak yang menggunakan pelaporan pajak melalui sistem direct dapat disebabkan oleh 2 (dua) faktor utama yaitu pertama, wajib pajak merasa lebih nyaman dan terbisa menggunakan pelaporan langsung, kedua wajib pajak belum memiliki kecakapan yang baik dalam melaporkan pajak secara modern (e-filling).

Dalam mengatasi faktor tersebut maka pemerintah dalam hal ini Direktorat Jenderal Pajak (DJP) bersama jajarannya dapat melakukan pendekatan-pendekatan yang sistematik untuk mendorong wajib pajak menggunakan e-filling sebagai sistem pelaporan pajak. Wajib pajak baik badan maupun pribadi selayaknya mendapatkan sosialisasi dan diberikan pelatihan secara langsung ataupun tidak langsung. Upaya ini bisa dilakukan langsung oleh jajaran Direktorat Jenderal Pajak (DJP) maupun oleh konsultan pajak sebagai pihak terdekat wajib pajak khususnya Badan. Dalam menyikapi kondisi saat ini yaitu pandemi covid19, maka sosialisasi e-filling dapat dilakukan dengan berbagi konten kepada masyarakat atau wajib pajak.

Konten yang menarik baik dalam bentuk video maupun diskusi atau jenis konten lainnya menjadi bagian penting dalam keberhasilan mendorong wajib pajak untuk beralih menggunakan e-filling dalam pelaporan pajak. Direktorat Jenderal Pajak (DJP) atau pihak lainnya yang berwenang dalam kebijakan perpajakan sudah waktunya untuk menerima masukan atau bekerjasama dengan pihak lain dalam mengatasi masalah pelaporan pajak oleh masayarakat. Masukan-masukan yang positif atau membangun dapat lebih diperhatikan dan diterapkan untuk menarik wajib pajak menggunakan e-filling, misalnya support server sistem online, penghargaan bagi wajib pajak yang menggunakan e-filling dan layanan customer service yang lebih cepat dalam menangani keluhan masyarakat ketika mengakses account. Era industri 4.0 yang kemudian "dipercepat" oleh pendemi covid 19 menjadi kesempatan Direktorat Jenderal Pajak (DJP) dalam meningkatan wajib pajak melaporkan pajaknya menggunakan efilling. Direktorat Jenderal Pajak (DJP) pada awal 2020 telah memperkenalkan dan meluncurkan aplikasi e-filling berbasis android yaitu klik pajak, Hal tersbut cukup tepat dilakukan, hanya beberapa kelemahan masih muncul dalam aplikasi tersebut, misalnya aktivasi account yang kurang praktis, integrasi antar data wajb pajak yang masih kurang sampai dengan kecepatan respons admin layanan keluhan wajib pajak yang dinilai masih kurang.

\section{SIMPULAN DAN SARAN}

Berdasarkan dari hasil penelitian tentang evaluasi penggunaan e-filling pada wajib pajak orang pribadi di KPP Pratama Pasar Minggu, maka dapat disimpulkan bahwa penggunaan e-filling merupakan modernisasi pajak yaitu perubahan teknologi dari pelaporan SPT secara manual beralih ke modern dengan menggunakan internet yang memiliki keberhasilan cukup baik. Pengguna e-filling terus mengalami peningkatan dari tahun ke tahun akan tetapi masih cukup banyak wajib pajak yang melaporkan pajaknya menggunakan cara tradisonal. Direktorat Jenderal Pajak (DJP) dapat melakukan upaya mendorong masyarakat atau wajib pajak menggunakan e-filling, melalui pedekatan terstruktur, pelatihan langsung dan tidak langsung, bekerjasama dengan konsultan pajak atau masyarakat serta menyempurnakan aplikasi pajak online berbasis android. 


\section{REFERENCES/DAFTAR PUSTAKA}

Direktorat Jenderal Perpajakan.(2017). Laporan Kinerja Direktorat Jenderal Perpajakan Indonesia. https://www.pajak.go.id/sites/default/files/2019-03/LAKIN DJP 2017.pdf

E.S. Wiradipradja dan D. Budhijanto. (2002). Budhijanto. In Cyber Law: Suatu Pengantar (p. 88). ELIPS II.

Gani, B. K., Wahyuni, E. D., \& Marthasari, G. I.(2020). Analisis Perilaku Penerimaan Penggunaan EFiling Menggunakan Pendekatan Theory Of Planned Behavior (TPB) Dan Technology Acceptance Model (TAM). Jurnal Repositor. https://doi.org/10.22219/repositor.v2i1.378

Mujiyati, Karmila, \& Wahyuningtyas, S. (2015). Faktor-Faktor yang Mempengaruhi Penggunaan E-Filing Bagi Wajib Pajak Orang Pribadi (Studi Empiris pada Wajib Pajak di KPP Sukoharjo dan KPP Surakarta). Syariah Paper Accounting FEB UMS, 2460-0784, 419-430.

Pemerintah Republik Indonesia. (2004). Undang-Undang Republik Indonesia Nomor 6 Tahun 1983 Tentang Ket (Placeholder1)entuan Umum Dan Tata Cara Perpajakan. Peraturan Pemerintah Republik Indonesia Nomor 26 Tahun 1985 Tentang Jalan, 1, 1-5.

Sukmadinata, N. S. (2009). Metode Penelitian Pendidikan. Remaja Rosdakarya.

Undang-Undang No. 28 Tahun 2007. (2007). Undang-Undang Republik Indonesia Nomor 28 Tahun 2007 Tentang Ketentuan Umum Dan Tata Cara Perpajakan. The Art of War. 